\title{
A National Study of Online Learning Leaders in US Higher Education
}

\author{
Eric E. Fredericksen \\ University of Rochester
}

\begin{abstract}
Online learning in US higher education continues to grow dramatically. The most recent estimates indicate that about $30 \%$ of all students enroll in at least one online course (Allen \& Seamen, 2016). As this important type of academic offering has become increasingly important to institutions of higher education, Presidents and Provosts have frequently established leadership positions to coordinate and direct their efforts in this area. But what do we know about the leaders who have been charged with managing this academic transformation? This systematic national study, a first of its kind, sheds light on the leadership that is guiding this new teaching and learning environment.
\end{abstract}

Keywords: online learning, leadership, higher education, academic transformation

Fredericksen, Eric E. (2017). A national study of online learning leaders in US higher education, Online Learning 21 (2) doi: 10.24059/olj.v21i2.1164

\section{Introduction}

To say that online learning is important for colleges and universities would be quite an understatement. As a percentage of overall enrollment, online learning continues to grow every year. As a result, it also grows in maturity and in terms of significance to institutions. The progress online learning has made has yielded notable attention and coverage from the media which in turn has increased its visibility to university executives and trustees. As a consequence, perceptions of the strategic importance of online learning to innovation at the university have increased. Yet, for such a vital endeavor, there has been a dearth of research and analysis about the leaders who guide its evolution. For university executives who are either creating or filling this role, this study has very practical implications as it synthesizes the skills, experiences, and background of the leaders who are directing these critical and innovative academic initiatives. 
The study also provides information about what groups are being reorganized and unified under these leaders.

Contributing to the vacuum in the research on online learning leadership is the lack of a comprehensive list of leaders, combined with the fact that this is a new senior role at many colleges and universities. This study began by addressing this issue with the systematic identification of online learning leaders. Of course, there are lists of presidents and provosts at the universities and colleges in the US but a database of leaders on online learning was not available. Thus, the first step in conducting this study was the identification of the online learning leaders and building a database of contact information for them. This process required the investigation of the institutional web sites of colleges and universities. Given the variety of sites and approaches, numerous methods were employed including searching organizational charts and cabinets of presidents and provosts using terms such as online learning /online education/ eLearning / distance education / distance learning/ instructional technology; reviewing Centers for Instructional Innovation or Teaching Excellence, Global Campus / World Campus / Extended Studies; investigating directories of Faculty / Staff / Office or the campus itself; and even conducting an examination of press releases. Frequently a combination of these tactics yielded the right individual, but in a minority of cases the person could not be identified. Sometimes the individual could be recognized in 5-10 minutes, but in most cases, it took much longer. Variations in the titles for these positions were common. As a safety net, communication and invitations requested that the individual identified please respond with the name of a more appropriate administrator if that was the case.

In order to guide and manage this effort, the author tried to take a systematic approach by organizing the search by the Carnegie Classification of the institutions. Institutions were explored in the following order: R1: Doctoral Universities - Highest research activity; R2: Doctoral Universities - Higher research activity; R3: Doctoral Universities - Moderate research activity; M1: Master's Colleges and Universities - Larger programs; M2: Master's Colleges and Universities - Medium programs; M3: Master's Colleges and Universities - Smaller programs. This approach provided solid organization and structure to the process. The goals of the study were:

- Develop a systematic and comprehensive list of leaders for online learning in US higher education

- Collect institutional data for context

- Gather information about the position and professional experience of the leader

- Capture demographic and other information about these individual leaders

- Investigate the potential relationships among these factors and dimensions

\section{Research Questions}

Our research questions are directly connected to the goals of this study:

1. What is the current state of online education at responding institutions?

2. What is the nature of the professional experience of current leaders of online education?

3. What are the background demographics of current leaders of online learning? 
These research questions guided the study and informed our methodology and survey instrument. For example, to explore the current state of online education at responding institutions it seemed essential to ask about the scope of online learning associated with the position, the highest level strategic goals for online learning at the institution, and whether the institution has used their online learning efforts as a catalyst for organizational change. Another fundamental area of discovery related to the professional experience of the leader and included questions about experience with face-to-face teaching, online teaching, management/leadership, instructional design, educational research, and IT. To better understand online learning leadership positions, questions were asked about the reporting relationship, whether the position included a faculty appointment, and how long the position has existed.

\section{Literature Review}

In order to assess the current state of higher education institutions and how the online learning executive might lead innovation within them, it is necessary and beneficial to first reflect on the complexity of higher education organizations. The nature of higher education and its culture does not typically yield a hierarchical structure with top-down or command-andcontrol decision making. Some organizational theories help us understand the environment of the college or university and how they function and therefore, help us appreciate how an online learning leader might need to operate. This background is helpful to our study as it situates the three research questions in the appropriate context. Leadership of innovation at a university is not the same as in the private sector. These theoretical considerations help us understand higher education, and this helps us appreciate the essential preparation of an effective online learning leader.

\section{Organized Anarchy}

University leaders face ambiguity (a state of uncertainty) from a number of dimensions and this affects their leadership and management abilities in "an organized anarchy" (Cohen \& March, 1986), a classic organizational theory which suggests higher education institutions function and achieve uncertain outcomes. Ambiguity is viewed through multiple lenses, the first is purpose which refers to the multiple, and oftentimes conflicting, goals of the institution. This is a classic characteristic of higher education and often includes academic excellence, research, and community service. Power in a university is an interesting capability that has a "chicken or the egg" quality to it. Leaders have power if they can accomplish things and they can accomplish things if they have power.

Presidents discover that they have less power than is believed, that their power to accomplish things depends heavily on what they want to accomplish, that the use of formal authority is limited by other formal authority, that the acceptance of authority is not automatic, that the necessary details of organizational life confuse power (which is somewhat different from diffusing it), and that their colleagues seem to delight in complaining simultaneously about presidential weakness and presidential willfulness. (Cohen \& March, 1986, p.17).

Another area of uncertainty is the ambiguity of experience, which underlines the challenges to learning faced by university leaders. The context of decisions is often complicated and outcomes are impacted by factors beyond the actions of a president. And while a leader may 
make great efforts to proceed with due diligence and collect and analyze information, the world is a dynamic and constantly changing place. Yes, experience is a great teacher, but positive or negative outcomes may have nothing to do with the decisions made by an administrator.

The fourth area is the ambiguity of success. Similar to experience, there can be issues regarding the indicators of success. At an individual level, a promotion might simply be the result of age, years of service, or the ability of the person to get a better job. As recognized above, the success of an institution may or may not be directly related to the actions of the leader. Cohen and March (1986) argue that the university executive, faced by the characteristics of an organized anarchy, has limited abilities and should not overestimate his or her power in institutional decision making.

\section{Loosely Coupled Systems}

One perspective on organizational theory that can help one understand higher education is the work of Karl Weick (1976) on loosely coupled systems. Weick describes loosely coupled as "the image that coupled events are responsive, but that each event also preserves its own identity and some evidence of its physical or logical separateness” (Weick, 1976, p.38). In a university setting, one can think of departments that are all part of the same division or school, but have little interaction and minimal response to each other. This can lead to inconsistencies or differences of approach from the same institution. While one might think of the disadvantages of this organization, the advantage is the latitude and independence gained by the individual unit. Of course, it should be noted that in an arena where the work is loosely coupled with minimal evaluation, tight controls identify who can do the work-in this case it is the faculty. And it is this loosely coupled environment that provides the faculty this ability for control.

Since some of the most important elements in educational organizations are teachers, classrooms, principals, and so forth, it may be consequential that in a loosely coupled system there is more room available for self-determination by the actors. If it is argued that a sense of efficacy is crucial for human beings, then a sense of efficacy might be greater in a loosely coupled system with autonomous units that it would be in a tightly coupled system where discretion is limited. (Weick, 1976, p.41).

So, given modest influence by senior administration and the loosely coupled organizational context, where does the power to make decisions about instructional innovation reside at the university? This author suggests that the faculty play a central role, based on the concept of the professional bureaucracy. And it is precisely this point that an online learning leader must understand and appreciate. Given that authority for making decisions about instruction resides with the faculty, the online learning leader must demonstrate a more collaborative approach. There must be an embrace of a transformational leadership style where the leader inspires change-a mandate or directive will not work. And recognizing that many faculty appreciate the perspective of their peers, this study also explores whether online leaders also hold a faculty appointment, and the extent of their teaching experience.

\section{Professional Bureaucracy}

Birnbaum's How Colleges Work defines bureaucracy as "the type of organization designed to accomplish large-scale administrative tasks by systematically coordinating the work of many individuals” (1988, p.107). However, the university setting is not a typical, hierarchical 
organization. While it may be tempered by a dean who has influence, the power and authority for academic innovation is mainly the purview of the faculty, a professional bureaucracy. When a school offers online education, it is often because the faculty has decided to do so. The professors will determine how fast or slowly this might happen. It is the domain of the professors, as they are closest to the students, to make the best decisions regarding instruction.

Mintzberg presents the concept of a professional bureaucracy which emphasizes the reliance on "coordination on the standardization of skills and its associated design parameters, training and indoctrination. It hires duly trained and indoctrinated specialists-professionalsfor the operating core, and then gives them considerable control over their own work. In effect, the work is highly specialized in the horizontal dimension, but enlarged in the vertical one. Control over his own work means that the professional works relatively independently of his colleagues, but closely with the clients he serves” (Mintzberg, 1979, p. 50).

The basic idea that is at the heart of higher education is that the faculty is the operating core of the academy. It is important to understand that the university is a decentralized institution with authority and decision making capability distributed across the enterprise. While there is some administrative hierarchy, the authority comes from the professions. That is, there is less "power of the office" and much more "power of expertise" (Mintzberg, 1979, p. 52). The expertise that drives authority in the institution is cultivated and valued by the academic departments. The complexity of the work leads to minimal evaluation and supervision. It is a collegial organizational structure where tenured faculty members are at the top and served by administrators and staff. In addition, the faculty members not only control their own work, they also try to control the role and decision making of the administration.

They also seek collective control of the administrative decisions that affect them, decisions, for example, to hire colleagues, to promote them, and to distribute resources. .... Every university professor, for example, carries out some administrative duties and serves on committees of one kind or another to ensure that he retains some control over the decisions that affect his work. (Mintzberg, 1979, p.56).

This standard approach, when dominated by faculty in a university, leads to a stable environment. The setting is complex, and the faculty members are comfortable in their role, with few revolutions.

It is precisely this decision-making power by faculty about instruction in higher education, as characterized by the concept of a professional bureaucracy, that determines the future of online education in colleges and universities. Faculty members are primary to academic decisions. They will determine alternative means of instruction and alternative means of assessment. Faculty members have always made these decisions for large lecture courses as well as small seminars. Online education simply represents another type of classroom with different affordances and constraints.

Higher education uses terms like "colleague" and "campus community" when referring to individuals and departments at the university. This seems to be in the spirit of what Baldridge refers to in his description of university collegium, as a community of scholars which emphasizes a "company of equals" and strong orientation around decision making by broad 
participation and consensus (Baldridge, Curtis, Ecker, \& Riley, 1977, p. 130). But again, when it comes to academic decisions, this community is often more strictly defined as the faculty.

This context of the culture and organizational nature of our universities underscores the importance of higher education experience for leaders of online education. And it situates the leader in a complex environment. To complement this and guide our study-especially related to the third research question about skills, experiences and background-it is also advantageous to consider the leadership approach of the individuals in these positions.

\section{Transformational Leadership}

This author suggests that the work of James Burns on transformational leadership might be the most helpful lens to consider. Burns compared transformational leadership to transactional leadership, a more basic or routine approach with a lower profile or role for the leader. Instead, Burns focused on the idea of transforming.

It is to cause a metamorphosis in form or structure, a change in the very condition or nature of a thing, a change into another substance, a radical change in outward form or inner character, as when a frog is transformed into a prince or a carriage maker into an auto factory. It is change of this breadth and depth that is fostered by transformational leadership. (Burns, 2003, p. 24).

This type of significant change might characterize the transition from traditional classroom courses to online courses. Transformational leadership is not a traditional or hierarchical command and control approach. It is collaborative; the leader engages the organization, creates a vision for the future, and even inspires innovation and change.

Bass and Riggio (2006) added to the work on transformational leadership by attending to the impact on follower motivation and performance. They describe four components of transformational leadership: Idealized Influence, Inspirational Motivation, Individual Consideration, and Intellectual Stimulation. In order for transformational leaders to be successful, they must employ one or more of these components. Given the complexity of higher education organization and the central role of faculty, it makes sense that an effective leader in this environment would need to be charismatic, inspire with challenge and persuasion, be intellectually stimulating, encourage faculty to use their abilities, and be individually considerate by providing faculty with support and coaching (Bass \& Riggio, 2006, p.5).

This study did not use the MLQ (Multifactor Leadership Questionnaire) to pinpoint the transformational leadership of the individuals. However, transformational leadership concepts can be a useful lens to frame what is needed to be effective in this field.

\section{Methods}

As noted earlier, a substantial effort was expended in order to develop a database of individual leaders for online learning and their contact information. Since this data was collected in waves, according to Carnegie classification-starting with R1 institutions, then R2, R3, M1, M2, and M3 (so far) - the invitations to participate in the study in Summer 2016 were also presented in chunks per the schedule below. 
A National Study of Online Learning Leaders in US Higher Education

R1 - initial invitation on June 8 with reminders on June 13, 20, 27

R2 - initial invitation on June 13 with reminders on June 20, 27 and July 5

R3 - initial invitation on June 20 with reminders on June 27 and July 5, 11

M1 (part 1) - initial invitation on June 27 with reminders on July 5, 11, 18

M1 (part 2) - initial invitation on July 5 with reminders on July 11, 18, 25

M2 - initial invitation on July 11 with reminders on July 18, 25 and August 1

M3 - initial invitation on July 18 with reminders on July 25 and August 1, 8

The survey consisted of 30 multiple-choice questions that utilize a Likert-type scale and two open-ended questions.

The first section of the survey instrument collected information about the university and helps us with data for our first research question about the current state of online education at the institution. The questions included:

What is the Carnegie classification of your institution?

Is your institution public or private?

Where is your institution located?

How do you and your institution define the scope of online learning for your position?

What are the highest level strategic goals for online learning at your institution?

How many years ago did your institution create a leadership position for online learning?

Has your institution used your online learning efforts as a catalyst for organizational changes?

If your answer to the previous question was yes, what groups at your institution have been unified within your organization?

Which of the following groups at your institution are under your direct responsibility?

Does your institution use any Online Education Service providers for specific functions?

What are the top priorities or issues related to online learning for you and your institution?

The second section of the survey instrument collected information about the professional experience of the online learning leader and helps us with the second research question. The questions included:

How many years have you held this position of leadership for online learning?

In addition to your leadership role for online learning, do you also hold a faculty

appointment?

How many years of traditional face-to-face classroom teaching experience do you have?

How many years of online teaching experience do you have?

How many years of management / leadership experience do you have?

How many years of instructional design / curriculum development experience do you have?

How many years of educational research experience do you have?

How many years of IT (Information Technology) experience do you have? 
The third section of the survey instrument collected information about the background of the online learning leader and helps us with the third research question. The questions included:

What is your gender?

What is your age?

Whom do you report to?

How many years have you served at your current institution?

How many years of experience do you have in higher education?

Which of the following degrees have you received?

Which of the following are fields in which you earned a degree?

Have you been an online student?

Which of the following organizations or associations do you or your institution belong?

I plan on attending events or conferences from the following organizations or

associations. Would you find it beneficial to develop a network of colleagues in this role and participate in that community?

How do you stay informed about the state of online learning? (peers, methods, research, technologies, vendors, etc.)

The study reached out to 820 individuals and 255 of them responded to this web-based survey-resulting in a 31\% response rate.

\section{Results}

The presentation of the results is organized and aligned by the goals and research questions of the study. As noted earlier, this included collecting institutional data for context, gathering information about the professional experience of the leader, and the background demographics of these individuals.

\section{Institutional Context}

A foundational question for this study related to how institutions defined the scope of online learning for this leadership position. Counter to any perceptions about strict alignment with distance education, $60 \%$ of responses indicated that the leader was responsible for supporting all types of courses at the institution, not just completely online courses or completely online and hybrid courses. This question was also explored by a number of variables through cross tabulations and chi square analysis. We found no statistical significance related to Carnegie classification, private / public, or any other variable.

Table 1 Scope for online learning

\begin{tabular}{|l|c|}
\hline $\begin{array}{l}\text { How do you and your institution define the scope of online learning for your } \\
\text { position? }\end{array}$ & $\%$ \\
\hline Completely online courses & $18 \%$ \\
\hline Completely online \& hybrid courses & $18 \%$ \\
\hline All courses & $60 \%$ \\
\hline Other & $4 \%$ \\
\hline
\end{tabular}


Another aspect related to institutional context was the strategic goal for online learning. The most selected strategic goal was "grow total institutional enrollments above existing levels" and was followed by "promote instructional innovation" and "promote student engagement." This emphasis on growing institutional enrollments was consistently the top strategic goal for both public institutions and private institutions. This was also true for all Carnegie classifications with one exception - the R1 institutions. For the highest level of research activity, the top goal selected was "promote instructional innovation."

This focus on aatracting new students seems to align with the study, Why Do Higher Education Institutions Pursue Online Education? which explored institutional motivation (Schiffman, Vignare, \& Geith, 2007). This research examined responses only from colleges and universities that were already offering online education to better understand what drove their engagement. The authors looked for statistical differences across institutional types and nine possible reasons for pursuing online education. The number one reason (57\%) selected by all institution types was "Get new students from new geographic regions or new markets of students" and the number two reason (46\%) was "Contribute to extension efforts" (Schiffman et al., 2007, p. 66).

Table 2 Highest level strategic goals

\begin{tabular}{|l|c|}
\hline What are the highest level strategic goals for online learning at your institution? & $\%$ \\
\hline Grow total institutional enrollments above existing levels & $82 \%$ \\
\hline Promote instructional innovation & $74 \%$ \\
\hline Promote student engagement & $67 \%$ \\
\hline Enhance student retention & $65 \%$ \\
\hline Reach out-of-state-students & $54 \%$ \\
\hline Reach international students & $31 \%$ \\
\hline Help maintain total institutional enrollments at existing levels & $24 \%$ \\
\hline Other & $12 \%$ \\
\hline
\end{tabular}

This study also captured when institutions created a leadership position for online learning. While there were some positions (29\%) that had been in place for more than 10 years, it is interesting to note that the majority of positions were created in the past 5-6 years. One might look back at what was happening in the field during this window of time, and perhaps speculate that the MOOC activity in higher education could have been a catalyst at some institutions. Online learning gained greater visibility in US higher education at that time and universities endeavored to decide on a strategy and direction for online learning. Breaking this down by Carnegie classification or public vs. private did not reveal differences that were statistically significant. 
Table 3 When leadership was created

\begin{tabular}{|l|r|}
\hline $\begin{array}{l}\text { How many years ago did your institution create a leadership position for online } \\
\text { learning? }\end{array}$ & $\%$ \\
\hline Less than 1 & $6 \%$ \\
\hline $1-2$ & $11 \%$ \\
\hline $3-4$ & $16 \%$ \\
\hline $5-6$ & $9 \%$ \\
\hline $7-8$ & $5 \%$ \\
\hline $9-10$ & $29 \%$ \\
\hline $10+$ & $6 \%$ \\
\hline I choose not to answer & $9 \%$ \\
\hline
\end{tabular}

Table 4 describes responses to an important question in this study: whether the responding institutions used online learning as a catalyst for organizational changes. A key finding was that almost 3 out of 4 responses were yes. For those who recognize the broad operational implications for online learning that can impact so many areas of a university, this might be not be surprising. Breaking this down by Carnegie classification, public vs. private, how many years ago the leadership position was created, to whom the position reported, and even whether the leader had a faculty appointment did not suggest differences that were statistically significant.

Table 4 Catalyst for organizational change

\begin{tabular}{|l|r|}
\hline $\begin{array}{l}\text { Has your institution used your online learning efforts as a catalyst for } \\
\text { organizational changes? }\end{array}$ & $\%$ \\
\hline Yes & $72 \%$ \\
\hline No & $28 \%$ \\
\hline
\end{tabular}

Related to the issue of organizational change, the study asked what groups had been unified within the oversight of the online learning leader. Certain units were noted more frequently than others. More than half of the respondents identified Instructional Design, Faculty Development and Training, Course Design and Multimedia Development, Learning Management Systems, Online Learning Policy Development, and Academic/Educational Technology as being unified under their leadership. The three units that were selected by less than half of the respondents included the Center for Teaching and Learning, Faculty IT Support, and Library Support for Faculty.

Breaking this down by Carnegie classification did reveal differences. While R1 and M1 institutions were consistent with the overall composite, less than half of the R2 institutions cited 
Academic/Educational Technology and Learning Management Systems as part of their responsibility, the majority of R3 institutions added the Center for Teaching and Learning, the majority of M2 institutions added Library Support for Faculty, and less than half of the M3 institutions included Online Learning Policy Development. Analyzing responsibilities by private and public institutions did not show any differences from the combined total responses.

Table 5 What groups were unified

\begin{tabular}{|l|r|}
\hline What groups at your institution have been unified within your organization? & $\%$ \\
\hline Instructional Design & $76 \%$ \\
\hline Faculty Development and Training & $69 \%$ \\
\hline Course Design and Multimedia Development & $65 \%$ \\
\hline Learning Management Systems & $62 \%$ \\
\hline Online Learning Policy Development & $59 \%$ \\
\hline Academic/Educational Technology & $42 \%$ \\
\hline Center for Teaching and Learning & $38 \%$ \\
\hline Faculty IT Support & $27 \%$ \\
\hline Library support for Faculty & $12 \%$ \\
\hline Not applicable - there have been no changes to our organization & \\
\hline
\end{tabular}

Respondents were also asked about their use of Online Education Service Providers. The largest number (37\%) reported that they did not use any. The most cited area (30\%) was for Learning Management System (LMS) hosting. A modest number (13\%) indicated the use of Marketing and Recruitment services, and 15\% stated that they are used for more than one function. With the exception LMS hosting, the use of service providers seems to be the exception, leaving colleges and universities to take advantage of internal resources and expertise.

Table 6 Use of service providers

\begin{tabular}{|l|r|}
\hline $\begin{array}{l}\text { Does your institution use any Online Education Service providers for specific } \\
\text { functions? }\end{array}$ & $\%$ \\
\hline We do not use any Online Education Service Providers & $37 \%$ \\
\hline Learning Management System (LMS) hosting. & $30 \%$ \\
\hline We use more than one & $15 \%$ \\
\hline Marketing and Recruitment & $2 \%$ \\
\hline Student Support & $2 \%$ \\
\hline
\end{tabular}




\begin{tabular}{|l|r|}
\hline Multimedia Development & $2 \%$ \\
\hline Curriculum Development & $1 \%$ \\
\hline Instructional Design & $1 \%$ \\
\hline Faculty Support & $0 \%$ \\
\hline
\end{tabular}

The last aspect of institutional context for this study related to the top challenges faced by the online learning leaders. Respondents were asked to rank order an extensive list of 14 issues, with 1 being the top priority. The top three priorities or issues were faculty development and training, strategic planning for online learning at your institution, and staffing for instructional design and faculty support. A change was noted when this was examined through the lens of a private or public institution. The number 3 priority for private institutions was marketing and promotion of online courses and programs and the number 3 priority for public institutions was funding and resources at your institution.

Table 7 Top priorities

\section{What are the top priorities or issues related to online learning for you and your} institution?

1. Faculty development and training

2. Strategic planning for online learning at your institution

3. Staffing for instructional design and faculty support

4. Funding and resources at your institution

5. Providing student support

6. Marketing and promotion of online courses and programs

7. Development of institutional policies for online learning

8. Ensuring academic integrity

9. State regulations and SARA (State Authorization and Reciprocity Agreement)

10. Evaluation / Implementation of learning management systems

11. Learning analytics

12. Conducting research about the effectiveness of online learning

13. Working with online education service providers

14. Development of a MOOC strategy 


\section{Summarizing the professional experience for the leadership position}

To start to understand the professional experience for these online learning leaders, respondents first reported on their length of service as an online learning leader. More than $70 \%$ have been in this position for the past 5-6 years (or less) and more than half for 3-4 years or less.

Table 8 Time in position

\begin{tabular}{|l|r|}
\hline How many years have you held this position of leadership for online learning? & $\%$ \\
\hline Less than 1 & $11 \%$ \\
\hline $1-2$ & $19 \%$ \\
\hline $3-4$ & $24 \%$ \\
\hline $5-6$ & $17 \%$ \\
\hline $7-8$ & $2 \%$ \\
\hline $9-10$ & $13 \%$ \\
\hline $10+$ & $4 \%$ \\
\hline I choose not to answer & \\
\hline
\end{tabular}

Given that online learning is part of the academic fabric of the university, the study inquired about whether the leader also held a faculty appointment. Half of the respondents did not hold any faculty appointment, 26\% held a non-tenure track appointment, and 24\% held a tenured or tenure track appointment. Breaking this down by Carnegie classification and public vs. private did not suggest differences that were statistically significant. Connecting the importance of this to professional bureaucracy, Mintzberg stated "Moreover, full-time administrators who wish to have any power at all in these structures must be certified members of the profession, and preferably be elected by the professional operators or at least appointed with their blessing” (Mintzberg, 1979, p.56).

Table 9 Faculty appointment

\begin{tabular}{|l|r|}
\hline $\begin{array}{l}\text { In addition to your leadership role for online learning, do you also hold a faculty } \\
\text { appointment? }\end{array}$ & $\%$ \\
\hline Yes - Tenure or tenure track professor & $24 \%$ \\
\hline Yes - Non-tenure track professor & $26 \%$ \\
\hline No & $50 \%$ \\
\hline
\end{tabular}

Nworie (2012) emphasized that distance education leadership is different from leadership in other areas of higher education. The notion that leading innovative programs in traditional institutions requires flexibility makes sense. Online learning leaders need to work across constituent groups at the university in order to be effective. This means working with faculty, 
staff, students and administration, and often as an intermediary between these groups. Hypothesizing that appropriate prearation for online learning leadership might manifest itself in a blend of professional experiences, the study explored six dimensions.

The first area was traditional face-to-face classroom teaching. Seventy percent of the respondents had at least six years of experience and $25 \%$ had more than 20 years.

Table 10 Face-to-face teaching experience

\begin{tabular}{|l|r|}
\hline $\begin{array}{l}\text { How many years of traditional face-to-face classroom teaching experience do you } \\
\text { have? }\end{array}$ & $\%$ \\
\hline I do not have any & $10 \%$ \\
\hline Less than 1 & $4 \%$ \\
\hline $1-5$ & $15 \%$ \\
\hline $6-10$ & $19 \%$ \\
\hline $11-15$ & $7 \%$ \\
\hline $16-20$ & $25 \%$ \\
\hline $20+$ & $1 \%$ \\
\hline I choose not to answer & $19 \%$ \\
\hline
\end{tabular}

The second area concerned online teaching. The response was that more than 3 out of 4 taught online for at least a year and about one half for more than 6 years.

Table 11 Online teaching experience

\begin{tabular}{|l|r|}
\hline How many years of online teaching experience do you have? & $\%$ \\
\hline I do not have any & $11 \%$ \\
\hline Less than 1 & $8 \%$ \\
\hline $1-5$ & $30 \%$ \\
\hline $6-10$ & $21 \%$ \\
\hline $11-15$ & $15 \%$ \\
\hline $16-20$ & $10 \%$ \\
\hline $20+$ & $2 \%$ \\
\hline I choose not to answer & $1 \%$ \\
\hline
\end{tabular}


The third area centered on management and leadership experience. The response was that 2 out of 3 have more than 11 years of management and leadership experience.

Table 12 Leadership experience

\begin{tabular}{|l|r|}
\hline How many years of management / leadership experience do you have? & $\%$ \\
\hline I do not have any & $1 \%$ \\
\hline Less than 1 & $11 \%$ \\
\hline $1-5$ & $22 \%$ \\
\hline $6-10$ & $23 \%$ \\
\hline $11-15$ & $23 \%$ \\
\hline $16-20$ & $20 \%$ \\
\hline $20+$ & $0 \%$ \\
\hline I choose not to answer & \\
\hline
\end{tabular}

The fourth area inquired about experience with instructional design and curriculum development. The response was that $62 \%$ of the respondents had more than 6 years of instructional design and curriculum development experience.

Table 13 Instructional design experience

\begin{tabular}{|l|r|}
\hline $\begin{array}{l}\text { How many years of Instructional Design / Curriculum Development experience } \\
\text { do you have? }\end{array}$ & $\%$ \\
\hline I do not have any & $13 \%$ \\
\hline Less than 1 & $21 \%$ \\
\hline $1-5$ & $23 \%$ \\
\hline $6-10$ & $15 \%$ \\
\hline $11-15$ & $15 \%$ \\
\hline $16-20$ & $9 \%$ \\
\hline $20+$ & $1 \%$ \\
\hline I choose not to answer & \\
\hline
\end{tabular}

The fifth area asked about educational research experience. The response was that about half of the leaders had 6 or more years of educational research experience. 
Table 14 Educational research experience

\begin{tabular}{|l|r|}
\hline How many years of Educational Research experience do you have? & $\%$ \\
\hline I do not have any & $14 \%$ \\
\hline Less than 1 & $6 \%$ \\
\hline $1-5$ & $30 \%$ \\
\hline $6-10$ & $21 \%$ \\
\hline $11-15$ & $13 \%$ \\
\hline $16-20$ & $9 \%$ \\
\hline $20+$ & $1 \%$ \\
\hline I choose not to answer & $7 \%$ \\
\hline
\end{tabular}

The sixth and last area asked about Information Technology experience. The response was that $60 \%$ of the leaders had at least one year of IT experience. It should also be noted that $36 \%$ of the leaders did not have any IT experience. This might underscore the fact that online learning is not an IT activity, but rather that the online learning leader is expected to collaborate with the IT organization for support for enabling platforms.

Table 15 IT experience

\begin{tabular}{|l|r|}
\hline How many years of IT (Information Technology) experience do you have? & $\%$ \\
\hline I do not have any & $36 \%$ \\
\hline Less than 1 & $14 \%$ \\
\hline $1-5$ & $17 \%$ \\
\hline $6-10$ & $9 \%$ \\
\hline $11-15$ & $10 \%$ \\
\hline $16-20$ & $10 \%$ \\
\hline $20+$ & $2 \%$ \\
\hline I choose not to answer & $9 \%$ \\
\hline
\end{tabular}

The importance of a blend of experience and ability was also reflected in comments made by the online learning leaders.

Collaboration seems to be the skill most in need for leaders in this field as we do not control much of anything. Redefining work as sharing information and presenting goals 
\& standards; working with department chairs to name faculty, ensure faculty training, schedule courses to lead to student persistence and degree completion are major challenges every day. (Participant survey, 2016)

The need for leaders to be versatile was also an attribute that emerged from the comments."Many different hats are required for this role - can't be an expert in all, but you need to be able to find those who are and who can help” (Participant survey, 2016).

Another participant offered perspectives on the right preparation for a leadership position.

A director of distance learning should ideally have a background in teaching, instructional design, and academic technology, as this is a multi-faceted role. Leadership training, knowledge of marketing, and a doctoral degree are also very helpful to establish credibility in an academic community. (Participant survey, 2016)

\section{About the individual leader}

The third area of inquiry for the study was focused on the personal characteristics of the individual leader. The initial effort to identify the appropriate individual provided data about gender. It also suggested that relative to this factor, the response sample is not dramatically different than the identified population.

Table 16 Gender

\begin{tabular}{|l|c|c|}
\hline & Identified Population & Sample \\
\hline Female & $410(50 \%)$ & $122(50 \%)$ \\
\hline Male & $410(50 \%)$ & $115(47 \%)$ \\
\hline Choose not answer & & $6(2 \%)$ \\
\hline Total & 820 & 243 \\
\hline
\end{tabular}

The question about age indicated that approximately 3 out of 4 of the respondents were 45 or older.

Table 17 Age

\begin{tabular}{|l|r|}
\hline What is your age? & $\%$ \\
\hline $18-24$ & $0 \%$ \\
\hline $25-34$ & $3 \%$ \\
\hline $35-44$ & $37 \%$ \\
\hline $45-54$ & $30 \%$ \\
\hline $55-64$ & $7 \%$ \\
\hline $65-74$ & $37 \%$ \\
\hline
\end{tabular}


A National Study of Online Learning Leaders in US Higher Education

\begin{tabular}{|l|c|}
\hline $75+$ & $0 \%$ \\
\hline I choose not to answer & $3 \%$ \\
\hline
\end{tabular}

The study was also interested in the reporting relationship for online learning leaders. More than half of the respondents stated that they reported to the Provost / Chief Academic Officer of the institution. There were some modest differences between public and private institutions. The second most selected role for public institutions was some Other Senior Academic Leader, but for private institutions, responses were tied between Other Senior Academic Leader and Directly to the President. It should be noted that despite the dependency on IT as a platform for online learning, only $5 \%$ of the leaders reported to the CIO. This might validate the view that online learning is not an IT function.

Table 18 Reporting relationship

\begin{tabular}{|l|r|}
\hline Whom do you report to? & $\%$ \\
\hline President & $5 \%$ \\
\hline Provost / Chief Academic Officer & $52 \%$ \\
\hline Other Senior Academic Leader & $23 \%$ \\
\hline Vice President / Senior Vice President (Outside of Academic Affairs) & $7 \%$ \\
\hline CIO (Chief Information Officer) & $5 \%$ \\
\hline Dean of a School & $3 \%$ \\
\hline Other & $5 \%$ \\
\hline
\end{tabular}

The study captured the length of service at their current institution as well as within higher education overall. Only $42 \%$ of the leaders have been at their current institutions for at least 11 years, but $86 \%$ have worked in higher education for at least 11 years-and $45 \%$ have worked in higher education for more than 20 years.

Table 19 Time at institution

\begin{tabular}{|l|r|}
\hline How many years have you served at your current institution? & $\%$ \\
\hline Less than 1 & $5 \%$ \\
\hline $1-5$ & $33 \%$ \\
\hline $6-10$ & $21 \%$ \\
\hline $11-15$ & $13 \%$ \\
\hline $16-20$ & $14 \%$ \\
\hline
\end{tabular}


A National Study of Online Learning Leaders in US Higher Education

\begin{tabular}{|l|c|}
\hline $20+$ & $14 \%$ \\
\hline I choose not to answer & $0 \%$ \\
\hline
\end{tabular}

Table 20 Time in higher education

\begin{tabular}{|l|r|}
\hline How many years of experience do you have in higher education? & $\%$ \\
\hline Less than 1 & $0 \%$ \\
\hline $1-5$ & $3 \%$ \\
\hline $6-10$ & $11 \%$ \\
\hline $11-15$ & $21 \%$ \\
\hline $16-20$ & $20 \%$ \\
\hline $20+$ & $45 \%$ \\
\hline I choose not to answer & $0 \%$ \\
\hline
\end{tabular}

Questions about academic preparation revealed that $62 \%$ of the leaders held a doctoral degree and the majority (54\%) held a degree in the field of education.

Table 21 Fields of academic credentials

\begin{tabular}{|l|c|}
\hline $\begin{array}{l}\text { Which of the following are fields in which you earned a degree? (check all that } \\
\text { apply) }\end{array}$ & $\%$ \\
\hline Education & $54 \%$ \\
\hline Business & $23 \%$ \\
\hline Humanities & $23 \%$ \\
\hline Social Sciences & $21 \%$ \\
\hline Other & $21 \%$ \\
\hline Technology & $20 \%$ \\
\hline Natural Sciences & $7 \%$ \\
\hline Computing & $6 \%$ \\
\hline Engineering & $3 \%$ \\
\hline Healthcare & $3 \%$ \\
\hline
\end{tabular}


The experience as a learner can be very valuable, so the study inquired about whether the respondent had been an online student. The majority (65\%) had been an online student - with $13 \%$ earning a complete online degree. However, this means that more than 1out of 3 did not have the experience of being an online student.

Table 22 Online student

\begin{tabular}{|l|r|}
\hline Have you been an online student? (credit bearing) & $\%$ \\
\hline Yes - one online course & $12 \%$ \\
\hline Yes - multiple online course & $40 \%$ \\
\hline Yes - an online degree program & $13 \%$ \\
\hline No & $35 \%$ \\
\hline
\end{tabular}

Professional development and connections to associations was the last area of inquiry for the study. Respondents reported on what organizations they belonged to with the top three being Online Learning Consortium (OLC), Educause Learning Institute (ELI), and Quality Matters (QM). They also indicated what events they planned on attending.

Table 23 Associations

\begin{tabular}{|l|c|c|c|c|}
\hline $\begin{array}{l}\text { Which of the following organizations or } \\
\text { associations do you or your institution } \\
\text { belong? (check all that apply) }\end{array}$ & Yes & $\begin{array}{r}\text { Yes - but } \\
\text { might drop }\end{array}$ & $\begin{array}{r}\text { No - but } \\
\text { might join }\end{array}$ & No \\
\hline OLC & $77 \%$ & $7 \%$ & $5 \%$ & $11 \%$ \\
\hline ELI & $67 \%$ & $8 \%$ & $3 \%$ & $22 \%$ \\
\hline QM & $61 \%$ & $12 \%$ & $1 \%$ & $27 \%$ \\
\hline WCET - WICHE & $52 \%$ & $11 \%$ & $0 \%$ & $37 \%$ \\
\hline UPCEA & $49 \%$ & $11 \%$ & $2 \%$ & $38 \%$ \\
\hline USDLA & $26 \%$ & $13 \%$ & $1 \%$ & $60 \%$ \\
\hline ISTE & $22 \%$ & $8 \%$ & $1 \%$ & $69 \%$ \\
\hline AECT & $10 \%$ & $11 \%$ & $2 \%$ & $78 \%$ \\
\hline NUTN & $9 \%$ & $9 \%$ & $1 \%$ & $82 \%$ \\
\hline ADEC & $5 \%$ & $12 \%$ & $1 \%$ & $83 \%$ \\
\hline ICDE & $13 \%$ & $1 \%$ & $84 \%$ \\
\hline
\end{tabular}


A National Study of Online Learning Leaders in US Higher Education

Table 24 Professional development conferences

\begin{tabular}{|l|r|}
\hline $\begin{array}{l}\text { I plan on attending events or conference from the following organizations or } \\
\text { associations. (check all that apply) }\end{array}$ & No \\
\hline OLC & $66 \%$ \\
\hline EDUCAUSE & $35 \%$ \\
\hline UPCEA & $30 \%$ \\
\hline WCET - WICHE & $28 \%$ \\
\hline ELI & $28 \%$ \\
\hline QM & $14 \%$ \\
\hline Other & $10 \%$ \\
\hline USDLA & $10 \%$ \\
\hline ISTE & $9 \%$ \\
\hline AECT & $4 \%$ \\
\hline NUTN & $3 \%$ \\
\hline ADEC & $0 \%$ \\
\hline ICDE & \\
\hline
\end{tabular}

Lastly, the leaders indicated their interest in connecting with peers. Seven out of eight respondents stated that they would value the opportunity to develop a network of peers and participate in that community.

Table 25 Interest in networking

\begin{tabular}{|l|c|}
\hline $\begin{array}{l}\text { Would you find it beneficial to develop a network of colleagues in this role and } \\
\text { participate in that community? }\end{array}$ & $\%$ \\
\hline Yes & $88 \%$ \\
\hline No & $12 \%$ \\
\hline
\end{tabular}

When asked to fill in an open-ended question about how they stay informed about the field, the leaders cited research, peers, and conferences/associations as the top three.

\section{Key Findings}

The bulleted list below provides a summarized list of the key findings of this study. 
- While $29 \%$ of the online learning leadership positions were created more than 10 years ago, the majority have been created in the past 5-6 years.

- Counter to a strict focus on distance education, more than $60 \%$ of the online learning leaders reported responsibility for supporting all types of courses.

- Almost 3 out of 4 respondents reported their institution was using online learning efforts as a catalyst for organizational change.

- The majority of online learning leadership positions report to the Provost of the institution.

- Overall, the top three highest level strategic goals reported were to:

- Grow institutional enrollments above existing levels,

- Promote instructional innovation, and

- Promote student engagement.

- The top three priorities or issues were:

- Faculty development and training,

- Strategic planning for online learning at the respective institution, and

- Staffing for instructional design and faculty support.

- The top three professional development associations the leaders belonged to were OLC, ELI, and QM.

- The reported use of external online learning service providers was very limited with the exception of hosting of the learning management system (30\%) and some modest efforts with marketing and recruitment (13\%).

\section{Discussion}

This study endeavored to help our field, our community, and higher education in general, to develop an understanding of the leaders who are guiding the critical academic transformation that supports online learning. The synthesis of the data about the individuals leading the transformation and their experiences leads to a composite description of very seasoned leaders with a blend of essential experience:

- $86 \%$ of leaders had more than 11 years of experience in higher education and $45 \%$ had more than 20 years

- $\quad 75 \%$ of leaders were at least 45 years’ old

- 2 out of 3 leaders held a doctoral degree

- Half of the respondents indicated that they also held a faculty appointment 
- The majority reported taking an online course(s), embracing the experience as an online student

- As expected, there was some variation in background, but most respondents had a blend of experience:

- $70 \%$ had at least 6 years of face to face teaching experience (and $1 / 4$ have more than 20)

- More than 3 out of 4 taught online for at least a year (half for more than 6 years)

- 2/3 had more than 11 years of management/leadership experience

- Half of the leaders had 6 or more years of educational research experience

- $62 \%$ of leaders had 6 or more years of instructional design experience

- $60 \%$ had at least one year of IT experience (but 36\% have no IT experience)

As one considers the results of this study, the author would suggest that university executives should be encouraged and optimistic about the success of online learning at their institutions as they count on and depend on these veteran leaders. There are practical implications, too.

University executives can benchmark their approach and their plans for online learning compared to other higher education institutions. For those senior leaders who are considering adjustments to their organizations, the study provides information about the groups and units that are being commonly unified under these new online learning leaders. For Presidents and Provosts who need to create or fill this position, hopefully this study will inform their thinking and provide insight on the background and experiences needed for their new leader.

Online learning leaders can self-assess their own background and experience as compared to the overall composite. They might evaluate areas of personal growth as well as consider the associations and conferences for networking and professional development. And the author would encourage the online learning leaders who have not studied online to enroll in an online course and gain that valuable perspective.

\section{Limitations}

The author must acknowledge that this study is limited by participants who provided data about themselves and their institutions. It was no small feat to reach out to all R1, R2, R3, M1, M2, and M3 institutions and the author is extremely grateful for their contributions to the study. But this means the baccalaureate colleges and community colleges were not represented at this time. It is the intention of the PI to expand the study to those institutions in the future. 


\section{References}

Allen, I. E., \& Seaman, J. (2016). Online report card: Tracking online education in the United States (First ed.). Needham, MA: Babson Research Group.

Bass, B., \& Riggio, R., (2006). Transformational leadership. Mahwah, NJ: Lawrence Erlbaum Associates, Inc., Publishers

Baldridge, V., Curtis, D., Ecker, G., \& Riley, G. (1977). Alternate models of governance in higher education. In M. C. Brown (Ed.), Organization \& governance in higher education (5th ed., pp. 128-142). Boston, MA: Pearson Customer Publishing.

Birnbaum, R. (1988). How colleges work: The cybernetics of academic organization and leadership (1st ed.). San Francisco, CA: Jossey-Bass.

Burns, J. (2003) Transforming leadership: The new pursuit of happiness. New York, NY: Grove Press.

Cohen, M., \& March, J. (1986). Leadership in an organized anarchy. In M. C. Brown (Ed.), Organization \& governance in higher education (5th ed., pp. 16-35). Boston, MA: Pearson Custom Publishing.

Nworie, J. (2012). Applying leadership theories to distance education leadership. Online Journal of Distance Learning Administration, 15 (5).

Mintzberg, H. (1979). The professional bureaucracy. In M. C. Brown (Ed.), Organization \& governance in higher education (5th ed., pp. 50-70). Boston, MA: Pearson Custom Publishing.

Schiffman, S., Vignare, K., \& Geith, C. (2007). Why do higher education institutions pursue online education? Journal of Asynchronous Learning Networks, 11(2), 61-71.

Weick, K. (1976). Educational organizations as loosely coupled systems. In M. C. Brown (Ed.), Organization \& governance in higher education (5th ed., pp. 36-49). Boston, MA: Pearson Custom Publishing. 